\title{
Online brand community strategy in achieving e-loyalty in the Indonesian e-commerce industry
}

\author{
Agus Kurniawan $^{a^{*}}$, Lili Adi Wibowo ${ }^{a}$, Agus Rahayua ${ }^{a}$, C. I. Yuliantia ${ }^{a}$, Tika Annisa ${ }^{a}$, and Ari Riswanto ${ }^{a, b}$
}

\author{
${ }^{a}$ Universitas Pendidikan Indonesia \\ Article history: \\ Received: April 15,2021 \\ Received in revised format: June \\ 28, 2021 \\ Accepted: July 5, 2021 \\ Available online: July 5, 2021 \\ Keywords: \\ e-commerce \\ Online brand community \\ e-loyalty \\ Marketing
}

${ }^{b}$ Sekolah Tinggi Keguruan dan Ilmu Pendidikan PGRI Sukabumi, Indonesia

\section{A B S T R A C T}

\begin{abstract}
This research aims to analyze the effect of Online Brand Community (OBC) on E-loyalty in the Indonesian e-commerce industry. This research was conducted by quantitative approach with the dependent variable of this research being e-loyalty $(\mathrm{Y})$, and online brand community $(\mathrm{X})$ as independent variable. The object includes all followers of Tokopedia, Bukalapak and OLX official Instagram accounts. The research uses a simple random sampling method and probability sampling techniques to 200 account users. Data analysis technique is implemented by using Structural Equation Modeling (SEM) with IBM SPSS AMOS version 22.0. The findings indicate the significant effect of online brand community on e-loyalty. The results theoretically imply the need for community engagement in online marketing as one of the online brand community's dimensions which can give the contribution of e-loyalty building.
\end{abstract}

\section{Background}

Loyalty is described as a positive attitude towards future purchases, also reflected in consumer commitment to a brand, as well as showing customer loyalty to certain objects, such as brands, products, services, or stores (Wahyuni \& Fitriani, 2015; Tjahyadi, 2006; Wibowo et al., 2020; Malhotra, 2015). Several researchers have noted that e-loyalty can be enhanced by the participation and commitment of the community or consumers online and in the online brand community, e-loyalty is expected not only to be influenced by voluntary customer participation in the community, but also by autonomous management of websites. In online brand communities that are initiated by consumers, there are information and experiences that are presented and can be trusted, customers tend to build a strong commitment to society, thereby building continuous e-loyalty or relevant branded products (Jang et al., 2008). The transaction process or core business of the object of this research, namely Tokopedia, Bukalapak and OLX, can be done using an integrated mobile application or official website to serve its customers. In addition to buying and selling websites, in order to build good relationships and communication with customers, the three companies open community pages (fan pages) on social media, such as Facebook, Instagram and Twitter. Some of the activities on the Instagram account contain graphic content that aims to communicate either one-way or two-way with consumers. Tokopedia, Bukalapak and OLX show several activities carried out by companies related to the dimensions of online brand community according to Hope et al. (2009), with the items of social networking, impression management, brand use, and community engagement.

* Corresponding author.

E-mail address: aguskrn@upi.edu (A. Kurniawan)

(C) 2021 by the authors; licensee Growing Science, Canada. doi: $10.5267 /$ j.ijdns.2021.7.002 


\section{Literature review}

Building and managing loyalty is one of the central themes that marketers have been researching for a long time (Erdoğmuş \& Cicek, 2012). The concept of customer loyalty was developed since the beginning of 1940 and has been widely researched by experts such as); Jacoby and Chestnut (1978); Oliver (1999) and has continued to develop until now (Afsar et al., 2013; Rai \& Srivastava, 2012). The concept of brand loyalty has developed around the last 60 years, its evolution has long been introduced by several scientists (Ha et al., 2011; Yeboah-ASiamah et al., 2016). The concept then was carried out theory development and research by several experts and continues to this day (Tucker, 1964; Jacoby \& Kyner, 1973; Bloemer \& Kasper, 1995; Oliver, 1999). Research on e-loyalty has been carried out in several industries, but mostly on the internet-based marketing industry, such as e-commerce, the e-retail industry, and others (Kim et al., 2009; Semeijn et al., 2005; Srinivasan et al., 2002; Khan \& Rahman, 2016). Currently, with the rapid development of technology and the internet, it has provided great support for changes in business activities, starting from how to advertise, how to buy and sell, to how to interact between people, known as e-commerce or online business (Synthiar, 2012). E-commerce is a type of electronic business mechanism that focuses on individual-based business transactions using the internet as a medium for exchanging goods or services between two institutions (B-to-B) and between institutions and direct consumers (B-to-C) (Pujastuti et al., 2014). Several studies have found that e-loyalty can be influenced by e-trust, e-satisfaction, e-services quality, customer characteristics, e-tail brand experience, and virtual/online community (Kim et al., 2009; Afsar et al., 2013; Wijaya \& Istriani, 2015; Anderson \& Srinivasan, 2003; Hendika et al., 2011; Semeijn et al., 2005; Hendika et al., 2011; Floh \& Treiblmaier, 2006; Khan \& Rahman, 2016; Gommans et al., 2001; Srinivasan et al., 2002). There is some literature stating that community or online community is part of the factors that can encourage the growth of e-loyalty (Gommans et al., 2001). Srinivasana et al. (2002) with the interview method identified eight factors of e-business that have an impact on e-loyalty, with the dimensions of customization, contact interactivity, cultivation, care, community, choice, convenience, and character. Thus, the online brand of community is part of the antecedents of the concept of e-loyalty. Online brand community is one part of the marketing communication or relationship marketing process as an effort to achieve brand equity and customer/brand loyalty during product competition. Relationship marketing involves establishing, developing, and maintaining a network of relationships between suppliers, service personnel, customers, and other stakeholders, covering issues with partnerships, alliances, mutual influence, and internal marketing (Morgan \& Hunt, 1994). Empirical studies on online brand communities usually adopt a company-based perspective, with a major focus on company activities, ceremonies, traditions, systems, quality of communication, sponsorship, awards, and bonuses (Jang et al., 2008; Hsieh \& Wei, 2017; Laroche et al., 2012).

\section{Methods}

The approach used in this research is the marketing management approach, especially regarding the effect of the online brand community on e-loyalty to Indonesian e-commerce customers. As for the research object as the dependent variable (endogenous), namely e-loyalty $(\mathrm{Y})$ including psychological involvement $\left(\mathrm{Y}^{1}\right)$, favoritism $\left(\mathrm{Y}^{2}\right)$, the sense of goodwill towards a product/service or brand $\left(\mathrm{Y}^{3}\right)$, positive WOM $\left(\mathrm{Y}^{4}\right)$ and repeated purchase behavior $\left(\mathrm{Y}^{5}\right)$ (Chaudhuri \& Holbrook, 2001; Chang et al., 2009; Pham et al., 2013). Furthermore, the research object as an independent variable (exogenous), namely online brand community $(\mathrm{X})$ with social networking sub-variables $\left(\mathrm{X}^{1}\right)$, impression management $\left(\mathrm{X}^{2}\right)$, community engagement $\left(\mathrm{X}^{3}\right)$, and brand use $\left(\mathrm{X}^{4}\right)$ (Hope et al., 2009). The data used consisted of primary and secondary data from several literatures. The survey method was used to collect respondents' responses. The unit of analysis used as the respondent in this study is the customer of the Indonesian e-commerce startup website. In terms of sample size, the sample size satisfied in SEM must be large (asymptotic). In theory, SEM generally has a sample of 200 to 400 for models that have indicators between 10 and 15 , in order to anticipate sampling errors. The number of samples in this study was 200, so this study uses Maximum Likelihood (ML) estimation because the ML estimation model can withstand non-formal data (Sarjono \& Julianita, 2015). This type of research is quantitative. The populations in this study were the followers of the official Indonesian E-commerce Instagram account. This study also uses a simple random sampling method using probability sampling techniques for 200 account users. The analysis technique used is the analysis of Structural Equation Modeling (SEM) with IBM SPSS AMOS version 22.0 for Windows. The model specification stage is concerned with the formation of an initial structural equation model, before estimating. This initial model is formulated based on a theory or previous research. The model used in this study was taken based on the theory from research by Jang et al. (2008) and from research by Michel Laroche et al. (2012) which obtained findings of a relationship between online brand community and brand loyalty (e-loyalty). (See Fig. 1).

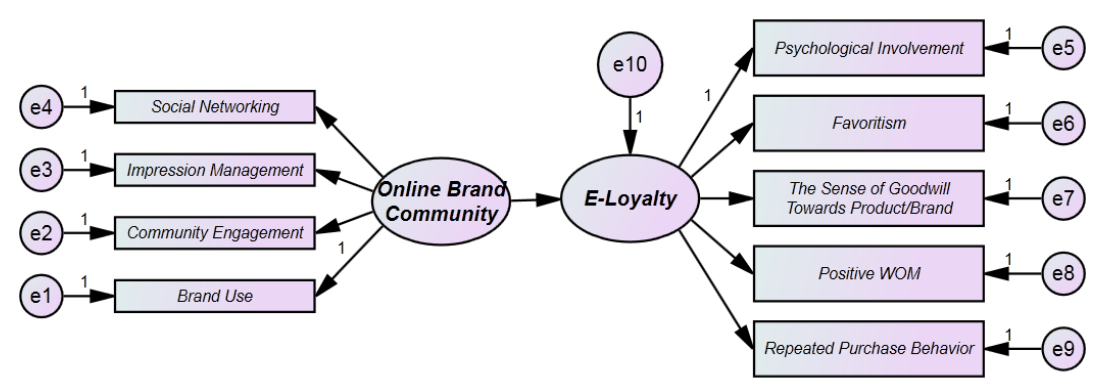

Fig. 1. Research Framework 


\section{Results}

The SEM analysis technique has several assumptions that must be met, consisting of sample size, data normality, data outliers, and multicollinearity. SEM has several basic assumptions that must be met before testing the effect of the research model, to find out whether model testing can be continued or not. The basic assumptions include sample size, data normality, data outliers and multicollinearity. In this study, all the basic assumptions of SEM are fulfilled, so that the data can be further processed for SEM analysis. The distribution of data must be analyzed through a normality test to see whether the assumption of normality is fulfilled so that the data can be further processed for modeling (Hair et al., 2014). Table 1 shows that all indicators and constructs that form each other in this research model can be said to be valid, because they show the results of the loading factor with a value $>0.5$. The loading factor with the highest results is the dimension of favoritism in forming eloyalty with a value of 0.921 . The lowest result is shown by the online brand community in forming e-loyalty with a value of 0.735 . Based on the measurement model estimation test, which shows the results of all dimensions and valid constructs $(>$ $0.5)$, the test can be carried out to the next stage, namely testing the structural model through the fit test.

Table 1

Measurement Model Estimation

\begin{tabular}{ccccc}
\hline & Relationship & & \\
\hline E-loyalty & $\leftarrow$ & OBC & OBtimate \\
BU & $\leftarrow$ & OBC & 0.735 \\
CE & $\leftarrow$ & OBC & 0.769 \\
IM & $\leftarrow$ & OBC & 0.848 \\
SN & $\leftarrow$ & E-loyalty & 0.838 \\
PI & $\leftarrow$ & E-loyalty & 0.830 \\
FV & $\leftarrow$ & E-loyalty & 0.865 \\
SGP & $\leftarrow$ & E-loyalty & 0,921 \\
PWOM & $\leftarrow$ & E-loyalty & 0.897 \\
RPB & $\leftarrow$ & 0.895 & 0.859 \\
\end{tabular}

Moreover, by testing the validity and reliability of the online brand community exogenous construct measurement model, it is known that all standardized loading factor values (SRW) for each indicator are more than 0.5 so it can be said that indicators of social networking, impression management, community engagement, and brand use have validity which is good at measuring the online brand community (OBC). To measure the reliability of the model, two measures are used, namely Construct Reliability (CR) and the average value of Variance Extract (AVE) with the standard of AVE value is $\geq 0.50$, and the CR is $\geq$ 0.70 while the reliability of $0.60-0.70$ is still acceptable provided that the validity of the indicators in the model is good (Table 2).

Table 2

Validity and reliability of constructs

\begin{tabular}{|c|c|c|c|c|c|c|c|c|c|}
\hline & \multirow{2}{*}{\multicolumn{2}{|c|}{ Relationship }} & & & \multirow[b]{2}{*}{ S.E. } & \multirow[b]{2}{*}{ C.R. } & \multirow[b]{2}{*}{$\mathrm{P}$} & \multirow{2}{*}{$\begin{array}{c}\text { Construct } \\
\text { Reliability } \\
(\geq 0.70)\end{array}$} & \multirow{2}{*}{$\begin{array}{c}\text { AVE } \\
(\geq 0.50)\end{array}$} \\
\hline & & & RW & SRW & & & & & \\
\hline \multicolumn{10}{|c|}{ Exogenous variables } \\
\hline $\mathrm{BU}$ & $\leftarrow$ & $\mathrm{OBC}$ & 1.000 & 0.752 & & & & 0.892 & 0.674 \\
\hline $\mathrm{CE}$ & $\leftarrow$ & $\mathrm{OBC}$ & 1.119 & 0.854 & 0.093 & 12.025 & $* * *$ & & \\
\hline IM & $\leftarrow$ & $\mathrm{OBC}$ & 0.966 & 0.856 & 0.081 & 11.907 & $* * *$ & & \\
\hline SN & $\leftarrow$ & $\mathrm{OBC}$ & 1.949 & 0.817 & 0.167 & 11.667 & $* * *$ & & \\
\hline \multicolumn{10}{|c|}{ endogenous variables } \\
\hline PI & $\leftarrow$ & e-loyalty & 1.000 & 0.866 & & & & 0.949 & 0.788 \\
\hline FV & $\leftarrow$ & e-loyalty & 2.042 & 0.918 & 0.108 & 18.910 & $* * *$ & & \\
\hline SGP & $\leftarrow$ & e-loyalty & 1.632 & 0.900 & 0.091 & 18.006 & $* * *$ & & \\
\hline PWOM & $\leftarrow$ & e-loyalty & 1.527 & 0.895 & 0.086 & 17.734 & $* * *$ & & \\
\hline RPB & $\leftarrow$ & e-loyalty & 0.861 & 0.857 & 0.053 & 16.258 & $* * *$ & & \\
\hline
\end{tabular}

Table 3 shows the estimation results of the online brand community model to e-loyalty. It shows the results of the significance test on the estimated path coefficients in the model after trimming, all of which are significant at an error rate of $5 \%$ or the $p$ value has a value of $<0.05$.

Table 3

Estimation results of the $\mathrm{OBC}$ on e-loyalty

\begin{tabular}{|c|c|c|c|c|c|c|}
\hline \multirow{2}{*}{ Model } & \multicolumn{2}{|c|}{ Estimate* } & \multirow{2}{*}{ S.E } & \multirow{2}{*}{ C.R } & \multirow{2}{*}{$\mathrm{P}$} & \multirow{2}{*}{$\mathrm{R}^{2}$} \\
\hline & RW & SRW & & & & \\
\hline E-loyalty $\leftarrow$ OBC & 0.202 & 0.735 & 0.021 & 9.649 & $* * *$ & 0.540 \\
\hline
\end{tabular}


Goodness of Fit Test as shown in Table 7 provides information that all measures of Goodness of Fit are in accordance with the recommendations and are greater than the cut off value, so it can be said that the overall model is fit. Good results are shown by the three criteria values for the fit model, namely the RMSEA value $0.063 \leq 0.08$ (fit), the AGFI value $0.8919 \geq$ 0.90 (fit), and the TLI value $0.982 \geq 0.90$ (fit).

Table 4

Goodness of fit test results

\begin{tabular}{|c|c|c|c|}
\hline Goodness-of-Fit Measures & Cut-off value & Result & Model Evaluation \\
\hline Statistic Chi-square $\left(\mathrm{X}^{2}\right)(\mathrm{df}=26)$ & $\chi^{2}$ stat. $<\chi^{2}$ table $(77.41858)$ & 46.212 & Fit \\
\hline GFI & $\geq 0.90$ & 0.953 & Fit \\
\hline RMSEA & $<0.08$ & 0.063 & Fit \\
\hline TLI & $\geq 0.90$ & 0.982 & Fit \\
\hline AGFI & $\geq 0.90$ & 0.919 & Fit \\
\hline CFI & $\geq 0.90$ & 0.987 & Fit \\
\hline PGFI & PGFI $<$ GFI & 0.551 & Fit \\
\hline PNFI & - & 0.701 & Fit \\
\hline
\end{tabular}

Moreover, hypothesis testing is performed using a t-value with a significance level of $0.05(5 \%)$ and degrees of freedom of $\mathrm{n}$ (sample). The results showed that the C.R value of the online brand community to e-loyalty is 9.649 , meaning that there is a positive influence on the online brand community on e-loyalty, with p-value of $0.00 \leq 0.05$. Thus, the hypothesis is accepted (Table 3). These results are supported by previous research which suggests there is a positive influence between online brand communities on brand loyalty or e-loyalty (Jang et al., 2008). The results also showed several matrices or estimation tables that show the relationship between the factors that make up a latent variable and its relationship with factors on other latent variables (Table 5).

Table 5

Implied Correlation of all variables

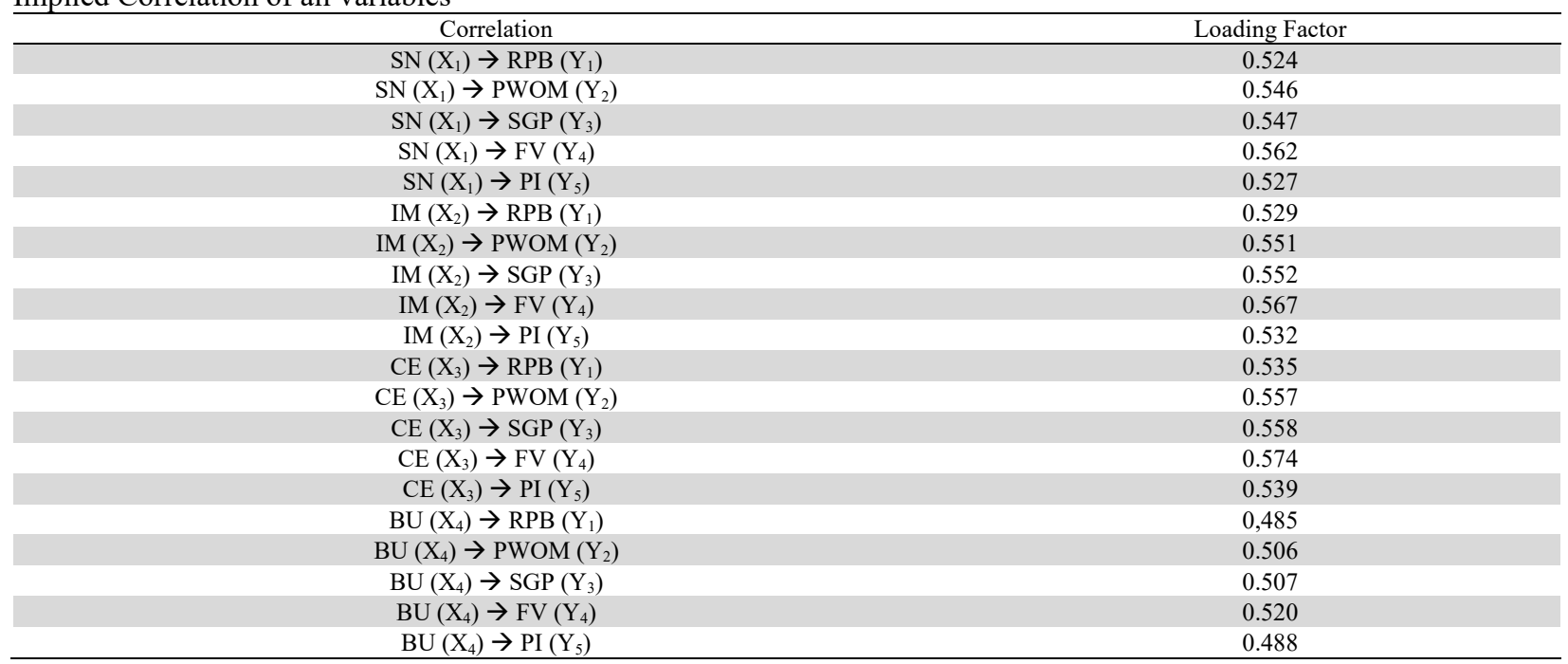

Table 8 shows the magnitude of the influence of the online brand community on e-loyalty which has a positive value is 0.202 seen from the unstandardized total effect output, or 0.735 when viewed from the standardized total effect output. It showed a positive and significant influence between the online brand communities on e-loyalty of 0.202 or 0.735 one-unit value. The value of the influence or loading factor of the online brand community dimension that forms e-loyalty is the dimension of community engagement which correlates with the dimension of favoritism in e-loyalty of 0.574 .

\section{Conclusion}

The findings showed the effect of online brand community and e-loyalty of Indonesian E-commerce. The online brand community has a positive and significant influence on e-loyalty to followers of the official Indonesian e-commerce Instagram account. This means that the online brand community can explain e-loyalty positively and significantly. This means that the better the online brand community management provided by the company, the better the e-loyalty that will be obtained from customers. The contribution given from the online brand community variable that is the biggest in forming e-loyalty is the dimension of community engagement which correlates with the dimension of favoritism in e-loyalty. Meanwhile, the dimension of online brand community that forms the smallest form of e-loyalty is the dimension of brand use which correlates with the dimension of repeated purchase behavior in e-loyalty. The author recommends companies that are in the Indonesian Ecommerce Industry to continue to improve their performance in managing online brand communities. Good online brand 
community management can keep customers from switching to other brands, so that it can foster customer e-loyalty for a company.

\section{References}

Afsar, A., Nasiri, Z., \& Zadeh, M. O. (2013). E-loyalty Model in e-Commerce. Mediterranean Journal of Social Sciences, 4(9), 547.

Anderson, R. E., \& Srinivasan, S. S. (2003). E-satisfaction and e-loyalty: A contingency framework. Psychology \& marketing, 20(2), 123-138.

Bloemer, J. M., \& Kasper, H. D. (1995). The complex relationship between consumer satisfaction and brand loyalty. Journal of Economic Psychology, 16(2), 311-329.

Chang, H. H., Wang, Y. H., \& Yang, W. Y. (2009). The impact of e-service quality, customer satisfaction and loyalty on emarketing: Moderating effect of perceived value. Total Quality Management, 20(4), 423-443.

Chaudhuri, A., \& Holbrook, M. B. (2001). The chain of effects from brand trust and brand affect to brand performance: the role of brand loyalty. Journal of Marketing, 65(2), 81-93.

Erdoğmuş, İ. E., \& Cicek, M. (2012). The impact of social media marketing on brand loyalty. Procedia-Social and Behavioral Sciences, 58, 1353-1360.

Floh, A., \& Treiblmaier, H. (2006). What keeps the e-banking customer loyal? A multigroup analysis of the moderating role of consumer characteristics on e-loyalty in the financial service industry. A Multigroup Analysis of the Moderating Role of Consumer Characteristics on E-Loyalty in the Financial Service Industry._(March 26, 2006).

Gommans, M., Krishman, K. S., \& Scheffold, K. B. (2001). From brand loyalty to e-loyalty: A conceptual framework. Journal of Economic \& Social Research, 3(1).

Ha, H. Y., John, J., Janda, S., \& Muthaly, S. (2011). The effects of advertising spending on brand loyalty in services. European journal of marketing.

Hair, J. F., Black, W. C., Babin, B. J., \& Anderson, R. E. (2014). Pearson New International Edition: Multivariat Data Analysis. Exploratory Data Analysis in Business and Economics, 23-60.

Hendika, S. L., Idrus, M. S., \& Suman, A. (2011). Pengaruh E-service Quality dan Net Oriented Lifestyle terhadap E-satisfaction dan E-loyalty (Studi pada Pelanggan E-ticketing di Kota Balikpapan). Jurnal Aplikasi Manajemen, 9(1), 85-93.

Hope, S. J., Muñiz Jr, A. M., \& Arnould, E. J. (2009). How Brand Communities Create Value. Journal of Marketing, 73(5), 30-51.

Hsieh, P. L., \& Wei, S. L. (2017). Relationship formation within online brand communities: Bridging the virtual and the real. Asia Pacific Management Review, 22(1), 2-9.

Jacoby, J., \& Chestnut, R. W. (1978). Brand loyalty: Measurement and management.

Jacoby, J., \& Kyner, D. B. (1973). Brand loyalty vs. repeat purchasing behavior. Journal of Marketing research, 10(1), 1-9.

Jang, H., Olfman, L., Ko, I., Koh, J., \& Kim, K. (2008). The influence of on-line brand community characteristics on community commitment and brand loyalty. International Journal of Electronic Commerce, 12(3), 57-80.

Khan, I., \& Rahman, Z. (2016). E-tail brand experience's influence on e-brand trust and e-brand loyalty. International Journal of Retail \& Distribution Management, 44(6), 588-606.

Kim, D. J., Ferrin, D. L., \& Rao, H. R. (2009). Trust and satisfaction, two stepping stones for successful e-commerce relationships: A longitudinal exploration. Information Systems Research, 20(2), 237-257.

Laroche, M., Habibi, M. R., Richard, M. O., \& Sankaranarayanan, R. (2012). The effects of social media based brand communities on brand community markers, value creation practices, brand trust and brand loyalty. Computers in Human Behavior, 28(5), 1755-1767.

Malhotra, N. K. (2015). Essentials of marketing research: A hands-on orientation. Essex: Pearson.

Morgan, R. M., \& Hunt, S. D. (1994). The commitment-trust theory of relationship marketing. Journal of Marketing, 58(3), 20-38.

Oliver, R. L. (1999). Whence consumer loyalty?. Journal of Marketing, 63(4_suppl1), 33-44.

Pham, T., Tomsfelt, J., \& Aberg, L. (2013). A Study about E-loyalty using the Bagozzi framework. Linnaeus University School of Business and Economics, Internet Address: http://www. divaportal. org/smash/get/diva2. 628701.

Pujastuti, E., Winarno, W. W., \& Sudarmawan, S. (2014). Pengaruh E-Commerce Toko Online Fashion Terhadap Kepercayaan Konsumen. Creative Information Technology Journal, 1(2), 139-153.

Rai, A. K., \& Srivastava, M. (2012). Customer loyalty attributes: A perspective. NMIMS Management Review, 22(2), $49-76$.

Ross, M. (1956). Brand Loyalty_-What, Where, How Much?. Harvard Business Review, 34(1), 116-128.

Sarjono, H., \& Julianita, W. (2015). Structural Equation Modeling (SEM): Sebuah Pengantar, Aplikasi untuk Penelitian Bisnis. Salemba Empat, 7.

Semeijn, J., Van Riel, A. C., van Birgelen, M. J., \& Streukens, S. (2005). E-services and offline fulfilment: how e-loyalty is created. Managing Service Quality, 15(2), 182-194.

Srinivasan, S. S., Anderson, R., \& Ponnavolu, K. (2002). Customer loyalty in e-commerce: an exploration of its antecedents and consequences. Journal of Retailing, 78(1), 41-50.

Synthiar, R. (2012). Perkembangan E-Commerce di Indonesia. Bandung: Universitas Pasundan.

Tjahyadi, R. A. (2006). Brand Trust dalam Konteks Loyalitas Merek: Peran Karakteristik Merek, Krakteristik Perusahaan, dan Karakteristik Hubungan Pelanggan-Merek. Jurnal Manajemen Maranatha, 6(1), 65-78. 
Tucker, W. T. (1964). The development of brand loyalty. Journal of Marketing research, 1(3), 32-35.

Wahyuni, S., \& Fitriani, N. (2017). Brand religiosity aura and brand loyalty in Indonesia Islamic banking. Journal of Islamic Marketing.

Wibowo, L., Widjajanta, B., Fadillah, A., Riswanto, A., Aprianti, V., Widjaja, Y., ... \& Romi, M. (2020). Supply chain analysis of hedonic shopping value on behavioral intention creation of multinational footwear company. Uncertain Supply Chain Management, 8(4), 745-752.

Wijaya, P. S. M., \& Istriani, E. (2015). Pengaruh Faktor-Faktor Anteseden E-Customer Satisfaction, E-Customer Trust Dan Compulsive Buying Pada Pembentukkan E-Customer Loyalty. Jurnal Manajemen, 19(1), 1-13.

Yeboah-Asiamah, E., Quaye, D. M., \& Nimako, S. G. (2016). The effects of lucky draw sales promotion on brand loyalty in mobile telecommunication industry. African Journal of Economic and Management Studies, 7(1), 109-123.

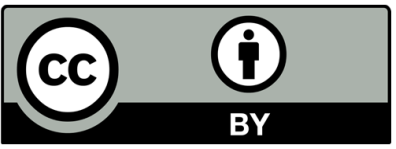

(C) 2021 by the authors; licensee Growing Science, Canada. This is an open access article distributed under the terms and conditions of the Creative Commons Attribution (CC-BY) license (http://creativecommons.org/licenses/by/4.0/). 